\title{
ВЗАИМОСВЯЗЬ БУХГАЛТЕРСКОГО УЧЕТА И СМЕЖНЫХ СФЕР ДЕЯТЕЛЬНОСТИ - НАЛОГООБЛОЖЕНИЯ, ПРАВА, АНАЛИЗА, АУДИТА
}

\author{
(c) 2021 Савин А. A. \\ кандидат экономических наук, профессор Департамента аудита и корпоративной отчетности \\ Финансовый университет при Правительстве Российской Федерации, Россия, Москва \\ E-mail: aasavin@fa.ru
}

Бухгалтерский учет как система сбора и обобщения информации об имуществе и обязательствах организации, а также учета всех операций, производимых этой организацией, тесно связан с другими сферами деятельности. Выполняя свою основную задачу, бухгалтерский учет предоставляет полную и достоверную информацию о деятельности организации и ее положении внутренним и внешним пользователям - руководителям, учредителям, собственникам, инвесторам, кредиторам. На этом этапе можно проследить взаимосвязь бухгалтерского учета с другими сферами деятельности.

Ключевые слова: учет, анализ, аудит, налогообложение, право, взаимосвязь

Бухгалтерский учет тесно связан с различными сферами деятельности: аудитом, анализом, налогообложением и правом. Далее детально разберем взаимосвязь бухгалтерского учета с каждой отдельной сферой деятельности. Бухгалтерский учет регулируется различными отраслями права: гражданское, административное, трудовое. Действующие нормативно-правовые акты в каждой конкретной отрасли регулируют отдельные аспекты бухгалтерского учета. Так, например, в гражданском праве, помимо того, что раскрываются базовые понятия, необходимые для организации бухгалтерского учета на предприятии, такие как правоспособность и дееспособность, юридическое лицо (ст. 48 ГК РФ), право собственности. Нормы Гражданского кодекса регулируют также следующие аспекты бухгалтерского учета: регулирование отношений между руководителем и главным бухгалтером, принцип имущественной обособленности, а также отражение имущества организации в бухгалтерском учете, отражение в бухгалтерском учете гражданско-правовых сделок, предписания законодательства, касаемо заключения договоров, отражение хозяйственных операций и т.д.

Принцип имущественной обособленности закреплен в ст. 48 ГК РФ, кроме того, юридическое лицо отвечает своим имуществом по всем своим обязательствам. Этот принцип отражается в ПБУ 1/2008 «Учетная политика организации», где установлено, допущение имущественной обособленности, которое предполагает, что: «активы и обязательства организации существуют обособленно от активов и обязательств собственников этой организации и активов и обязательств других организаций».

В параграфе 2 ГК РФ в зависимости от типа коммерческих организаций определяется исполнительный орган (руководитель организации), который представляет юридическое лицо, а также приобретает его права и принимает обязанности. Детально степень ответственности руководителя организации и главного бухгалтера за ведение дел внутри организации и отражение их в бухгалтерском учете, а также отношения «руководитель-главный бухгалтер» установлены в ФЗ № 402 «О бухгалтерском учете». Так, руководитель организации обязан организовать ведение бухгалтерского учета, а также возложить ведение бухгалтерского учета на главного бухгалтера. Таким образом, главный бухгалтер становится ответственным за ведение бухгалтерского учета и формирование учетной политики организации (ст. 7 ФЗ № 402).

Большая часть хозяйственных операций организации, которые впоследствии отражаются в бухгалтерской отчетности, выполняется путем заключения двусторонних или многосторонних договоров. Этот вопрос регулируется главой 27 ГК РФ. Так, например, устанавливается необходимость соответствия заключаемых договоров императивным нормам, а также влияние появления новых законов на уже заключенные договоры (ст. 422 ГК РФ), ст. 421 ГК РФ определяет применение диспозитивных норм и деловых 
обычаев при заключении договоров.

Административное право определяет степень ответственности лиц, организующих хозяйственные процессы организации, в том числе, определяет ответственность главного бухгалтеpa, как лица, ответственного за ведение бухгалтерского учета в организации. Ответственность за правонарушения, совершенные бухгалтером предусмотрена статьями 15.3-15.6 и 15.11 КоАП РФ. В частности, согласно ст. 15.11 КоАП РФ, за грубое нарушение требований к бухгалтерскому учету предусмотрено наказание в виде наложения штрафа на сумму от 5 до 10 тысяч рублей. При этом, под грубым нарушением требований понимается занижение сумм налогов и сборов, занижение показателей, искажение информации в бухгалтерском учете путем ведения счетов вне установленных регистров или не на основе реальных данных.

Нормы трудового права также находят свое применение в бухгалтерском учете, поскольку они регулируют вопросы касательно начисления заработной платы или других выплат, например, по отпускам, больничным, командировкам, вычисление материальной ответственности сотрудников и т.д. Бухгалтерский учет тесно взаимосвязан с налогообложением, поскольку бухгалтерская отчетность является объектом контроля налоговых органов с точки зрения полноты уплаты налогов. НК РФ устанавливает приоритет налогового учета над бухгалтерским. Однако, в реальности, несмотря на некоторую схожесть в их ведении, возникают значительные расхождения, вызванные разными методами признания расходов в налоговом и бухгалтерском учете. Так, в бухгалтерском учете расходы признаются вне зависимости от дальнейшего получения выручки, в то время как, в налоговом учете расходами признаются только те, которые повлекли за собой получение выручки. В конечном итоге, доходы, учтенные в бухгалтерском и налоговом учете, будут совпадать, но это не отменяет отсутствия расхождений при организации ведения учетов.

Кроме этого, бухгалтерский отдел решает вопросы налогообложения. Особенно часто вопросы из этой зоны ответственности передаются бухгалтерскому отделу на крупных и средних предприятиях. При таком распределении обязанностей, в задачи отдела входит корректное исчисление и учет налоговых платежей и составление налоговых деклараций.
Под экономическим анализом деятельности предприятия понимается совокупность методов изучения информации о результатах деятельности организации с целью оценки результативности его работы, оценки текущего финансового состояния компании, выявления неиспользованных резервов для повышения эффективности деятельности. Экономический анализ подразумевает использование максимума доступной информации для изучения различных аспектов функционирования организации. Ключевая цель анализа - это разработка и внедрение управленческих решений, направленных на оптимизацию работы организации.

Бухгалтерский учет имеет прямое отношение к экономическому анализу деятельности предприятий, т.к. является непосредственным источником информации касательно всех хозяйственных операций предприятия. Анализ бухгалтерской отчетности является способом принятия решений относительно инвестирования или кредитования. При этом, на основании бухгалтерской отчетности можно сделать вывод о финансовой независимости предприятия и его платежеспособности.

На основании бухгалтерского баланса предприятия можно сделать вывод об эффективности размещения активов предприятия, дать оценку размерам и эффективности инвестированных денежных средств. Бухгалтерский баланс иллюстрирует взаимосвязь активов и пассивов предприятия, а также их структуру, ликвидность активов и обеспеченность компании активами.

Основываясь на сравнении собственного капитала с внеоборотными активами и долгосрочными обязательствами, можно сделать вывод о финансовой устойчивости компании. На основании этого показателя можно сделать вывод о зависимости предприятия от заемного капитала.

Оценка ликвидности баланса организации показывает возможность организации погасить с собственные краткосрочные обязательства, и в отличие от предыдущего показателя, анализ ликвидности показывает стабильность предприятия в текущий период времени, т.е. в краткосрочном периоде.

Важным аспектом анализа бухгалтерского баланса предприятия является анализ его показателей в динамике. Например, рост активов компании демонстрирует рост и развитие бизнеса, а рост собственного капитала увеличивает финансовую устойчивость компании в долго- 
срочной перспективе. Кроме того, большое внимание уделяется анализу структуры активов и пассивов в динамике, т.к. рост доли оборотных активов связан с наращиванием избытков и, соответственно, демонстрирует неэффективность производственных процессов на предприятии.

Анализ отчета о прибылях и убытках позволяет сделать выводы относительно эффективности принятия управленческих решений в частности, и эффективности деятельности предприятия в целом. Анализ отчета о финансовых результатах позволяет сделать выводы о рентабельности предприятия, динамике его развития и структуре затрат.

При вертикальном анализе происходит сравнение структуры затрат путем подсчета доли всех статей отчета. Обычно такой метод применяется в краткосрочном периоде и по его показателям можно судить за счет увеличения или уменьшения каких статей произошли изменения в прибыли предприятия. При горизонтальном анализе сравнивается относительное изменение ключевых показателей отчета. Такой анализ чаще всего применяется для учета изменений за несколько лет и демонстрирует изменения в долгосрочной перспективе. Отдельно по отчету о финансовых результатах рассчитывается показатель рентабельности и показатели использования отдельных активов. Расчет рентабельности происходит путем сравнения прибыли предприятия с собственным капиталом и, таким образом, это показатель иллюстрирует, насколько эффективно был вложен инвестированный капитал. Суть анализа отдельных показателей использования активов сводится к тому, что высчитывается отношение выручки к размерам определенного актива. Таким образом, этот показатель показывает, сколько денежных средств принесло вложение одной единицы данного актива. Так, если при сравнении показателя с аналогичным показателем прошлого периода наблюдается рост, то можно судить об эффективном распределении ресурсов на предприятии, поскольку каждая единица вложенного актива приносит больше выручки, чем в прошлом периоде.

Аудиторская проверка является основным контрольным инструментом для поддержания полноты и достоверности информации, отражаемой в бухгалтерской отчетности. Внутренний аудит может проводиться собственными силами организаций, например, с целью проверки учета при смене бухгалтера. Однако, независимым и обязательным аудитом является только внешний, проводимый специалистами сторонних аудиторских компаний. Очевидно, что доверие к аудиторскому заключению со стороны внешних пользователей бухгалтерской информации может быть только по отношению к внешнему аудиту. Кроме того, только результаты внешнего аудита имеет юридическую силу в налоговых органах. Обязательным условием для проведения аудиторской проверки на предприятии является то, что аудитор обязан разбираться в системе бухгалтерского учета, которая применяется на конкретном проверяемом им предприятии.

Достоверность информации в бухгалтерской отчетности важна, в том числе, для проведения экономического анализа деятельности предприятия. Решение о целесообразности проведения анализа принимается в том числе, путем ознакомления с результатами аудиторской проверки, поскольку адекватный анализ деятельности предприятия возможен только на основании достоверных данных.

Таким образом, бухгалтерский учет невозможно рассматривать как отдельную сферу деятельности в отрыве от других смежных сфер. Поскольку, бухгалтерский учет является источником информации не только для внутренних пользователей информации, но и для внешних, эта сфера деятельности тесно связана со многими другими.

Так, информация, отражаемая в бухгалтерском отчете, не может противоречить нормам гражданского и трудового права, поскольку операции, отражаемые в бухгалтерской отчетности, регулируются нормативно-правовыми актами этих отраслей права. Бухгалтерский отчет также не может противоречить и нормам налогового права, поскольку, информация, подготавливаемая бухгалтерами, является объектом пристального внимания со стороны налоговых органов. Экономический анализ деятельности предприятия предоставляет структурированную информацию, высчитанную на основе бухгалтерских отчетов, для внутренних и внешних пользователей, на основании которой можно сделать выводы об эффективности функционирования предприятия.

Аудиторские проверки являются инструментом контроля за соблюдением норм ведения бухгалтерской отчетности, установленными на государственном уровне. Благодаря аудиторам, 
внешние пользователи информации могут получить достоверную информацию о реальном состоянии предприятия.

Таким образом, все сферы не только связаны с бухгалтерским учетом, но и связаны меж- ду собой, поскольку так или иначе регулируют ту информацию, которая находит отражение в бухгалтерской отчетности, а затем используется внутренними и внешними пользователями для принятия управленческих решений.

\section{Библиографический список}

1. Гражданский кодекс Российской Федерации. Часть I - http://www.consultant.ru/document/cons doc LAW $5142 /$

2. Кодекс Российской Федерации об административных правонарушениях - http://www.consultant.ru/ document/cons doc LAW 34661/

3. Положение по бухгалтерскому учету «Учетная политика организации» (ПБУ 1/2008) - http://www.consultant. $\mathrm{ru} / \mathrm{document} /$ cons doc LAW 81164

4. Федеральный Закон «О бухгалтерском учете» от 06.12.2011 № 402-ФЗ - http://www.consultant.ru/document/ cons doc LAW 122855/

5. Налоговый кодекс Российской Федерации - http://www.consultant.ru/document/cons doc LAW 19671/ 